\title{
Best Practices And Exemplary Applications Of Technology In Higher Education
}

Susan P. Lee, (Email: slee@deltastate.edu), Delta State University

Lynn J. House, (Email: lhouse@deltastate.edu), Delta State University

\begin{abstract}
The Center for Teaching and Learning (CTL) located in the College of Education at Delta State was envisioned in the 1999-2000 school year as a catalyst for systemic change across the college and region as related to technology and its place in the education of the P-12 community. The Center's goals include: 1) implementing appropriate standards for technology and high quality educator preparation programs across the graduate and undergraduate curricula, 2) providing access to technology for students and faculty in a variety of settings within the college, 3) providing access to state-of-the-art, technologically resource-rich environments for PK-12 partner schools and the greater community, 4) supporting web-based teaching and learning components, and 5) expanding e-learning capabilities to meet regional needs. The staff of the CTL provides on-going, on-site training and technical support for the greater DSU community. The Technology Coordinator for the College, the CTL Director and a Technical Specialist provide a full range of services for all CTL users. Student staff members in the Center for Teaching and Learning (CTL) have been a vital and valuable component of the Center's success. The student staff members provide individual and small group training and support for a wide range of technological applications including Web CT and the full complement of Microsoft Office programs.
\end{abstract}

\section{THE E-LEARNING PROGRAM}

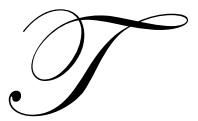

he Delta State University E-Learning Pilot Program was implemented in the 2004-05 school year as a new initiative of the Center for Teaching and Learning. The pilot allowed the university to identify the most efficient means for developing a full-scale e-learning program for Delta schools. A needs assessment conducted with area school districts determined that Spanish language classes should be included in the pilot. During the pilot year, a certified Spanish teacher appropriately trained in distance learning techniques taught classes to 60+ students via an interactive video system. Because the pilot year proved to be very successful, additional funding to continue the program was sought and provided from the State Board of the Institutions of Higher Learning and the Mississippi Department of Education.

The Technology Coordinator for the College of Education provides oversight for the E-Learning Program with the involvement of the Executive Director of the Delta Area Association for the Improvement of Schools (DAAIS) and the Dean of the College of Education. The staff of the CTL supports the technical aspects of the program. Mississippi Public Broadcasting serves as the connectivity bridge between the school districts and the university while Delta State University provides financial and managerial oversight for the program.

Participating school districts have provided appropriate classroom space and on-site equipment including computer access for students. Additionally, districts have purchased textbooks and workbooks, provided a classroom facilitator, and made technical support available as needed.

Qualitative data obtained through multiple school site visits, email correspondence and written feedback from students and school personnel formed the basis of the evaluation of the pilot program. All evaluative information indicated a very high degree of satisfaction with the e-learning pilot. Additional evaluation strategies will be employed at the end of the 2005-06 school year and will focus on student/teacher success, technology 
effectiveness, and efficiency of program operations. Evaluation results will be used in planning subsequent years of the E-Learning Program.

The major components of the E-Learning Program include the following:

- $\quad$ Two interactive video studios used to broadcast classes to area schools;

- $\quad$ Fully certified faculty providing instruction in advanced courses;

- $\quad$ Appropriate staff to ensure efficient operation and sufficient technology support;

- $\quad$ State-of-the-art equipment for operations and broadcasts;

- $\quad$ Training for Center faculty/staff and district personnel; and

- $\quad$ Collaborative structures to foster strong communication among districts, university personnel, and Center staff.

Five area high schools with a total of 208 students are currently enrolled in e-learning classes of Spanish I and Spanish II for the 2005-06 school year. Plans are to expand the program to include additional faculty to teach advanced placement classes and to offer enrichment activities in the arts as an after-school component.

\section{TEK PAKS}

Although teacher candidates have the responsibility of including technology in their field experience lesson presentations, many Delta area schools do not provide the technology needed for teacher candidates to be successful in this aspect of their teaching. The Office of Field Experiences and the Center for Teaching and Learning have equipped TEK PAKS for student to check out and use during their field experiences. Each TEK PAK includes a digital still camera, a digital movie camera, a Tablet PC, and an LCD projector to provide teacher candidates with the most up-to-date technology tools needed for the immersion of technology into their lessons. Additionally, teacher candidates are provided with appropriate training and support to allow them to be successful in their technology implementation.

\section{Resource Training Site}

It is fully recognized that simply "having" technology is not the same as "using" technology. With this in mind, the CTL has positioned itself to serve as a resource to university faculty and students, teachers and administrators in the PK-12 schools, and other community entities in developing an appropriate level of confidence in the use of a variety of technological tools.

College of Education faculty ensure that all teacher education students are aware of the expectations of their program in building the capacity to positively impact technology use in their schools. Class training, small group sessions, individual tutoring, and tutorial software are all provided to students to assist in their development in effective technology use. Faculty training sessions and individual assistance is also provided in the CTL Faculty Development area. This section of the CTL allows faculty privacy for tutoring sessions when developing their technology skills.

The College of Education at DSU partners with the Delta Area Association for the Improvement of Schools (DAAIS) in working toward meeting the needs of the PK-12 community. The consortium is composed of 30+ school district members as well as a local community college and is housed in the College of Education. This physical proximity allows appropriate planning and collaboration to take place with member schools. Training sessions within the Center for Teaching and Learning, on-site training provided at individual schools, and individual and small group assistance are all regular features of the work of the CTL with our partner schools.

Additionally, the CTL is available to community entities for training sessions as needed. Because the training facilities are state-of-the-art, they provide community members with an excellent location at which to meet their training needs. 
Demystifying technology and focusing on its applicability to improve the quality of life and services in the Delta region have served as the two focal points for all CTL endeavors.

\section{The Portable Lab}

A portable lab with wireless connectivity and 20 state of the art lap top computers is available to faculty for use in their classrooms. Each lap top is equipped with all software applications available to students and faculty in the Center for Teaching and Learning training lab. The increasing use of technology by all programs in the College of Education has been evidenced by the large number of reservation requests for the training lab. The portable lab offers faculty members an alternate solution for technology use when the CTL training lab is not available.

\section{Mini-Labs}

Mini-Labs containing program-specific software and 5-8 computers have been provided through the CTL for several programs within the college. These labs allow faculty close proximity to computer use for research activities with their students. The labs provide an invaluable service in promoting student research activities in a user-friendly environment and support the belief that research can inform practice.

\section{Technology Assessment for Teacher Education and Leadership Preparation Programs}

The College of Education at Delta State University has created a Technology Assessment for Teacher Education and Leadership Preparation programs. Using a technology model created through a $\mathrm{PT}^{3}$ grant at the University of Southern Mississippi as a model, the College of Education Technology Assessment consists of four modules, each of which assesses basic computer skills in the areas of word processing, multimedia presentations, telecommunications, and databases/spreadsheets. Students complete each module on the computer, banking each portion successfully completed and receiving the opportunity for instruction on portions needing remediation and reassessment. The successful completion of this assessment is a requirement for admission to Teacher Education and for completion of Leadership Preparation programs.

\section{The Learning Curve}

An increasing number of students come to Delta State University with deficiencies in one or more areas of basic skills. In an effort to assist these students, the College of Education has created The Learning Curve, a lab within a lab in The Center for Teaching and Learning. The Learning Curve provides computer-assisted instruction and technology support to students under the tutelage of the Tech Fellows. Faculty members send students to the CTL using referral forms noting areas in which students need improvement. Students receive instruction in generating programs and sites to help with their remedial areas.

Successful remediation and assessment will be reported to the appropriate faculty member(s) and tracked by The Center for Teaching and Learning.

\section{TASKSTREAM TOOLS OF ENGAGEMENT}

The College of Education has adopted the use of TaskStream Tools of Engagement for programs involved in the preparation of teacher candidates. TaskStream, a commercial based tool for collecting data and assessments, provides an array of web-based tools for teacher education programs. Faculty and administrators manage and distribute course materials, review student work and track student progress, create portfolio templates and assess student portfolios online, develop curriculum easily referencing state and national standards, and prepare assessment rubrics. TaskStream's reporting tools aggregate and disaggregate data for accreditation support.

Students submit work for review and evaluation, receive feedback from instructors and peers, and author standards-based lessons and units. TaskStream's Web Folio Builder makes it easy for students to create, organize, and share electronic portfolios that demonstrate standards compliance for certification. Instructors create online 
programs through which they distribute course materials and review students work. Delta State University College of Education students access these class resources and submit work to their instructors online. Email and instant messaging systems facilitate collaboration, and faculty members establish discussion groups and post announcements for their classes to support multiple modes of communication.

\section{Outcomes}

The success of The Center for Teaching and Learning can be seen in the increased number of students, faculty, and school districts making use of the services. As an example, data collected since the CLT opened shows a dramatic increase as noted below:

Chart 1

Summary Of CTL Usage Data

\begin{tabular}{|c|c|c|}
\hline Student Lab Use & Training Lab Use & Equipment Reservations \\
\hline $1999-2000-2011$ & & \\
\hline $2000-2001-7416$ & & \\
\hline $2001-2002-8623$ & & \\
\hline $2002-2003-15508$ & & $2003-2004-247$ \\
\hline $2003-2004-16011$ & $2003-2004-4374$ & $2004-2005-338$ \\
\hline $2004-2005-16876$ & $2004-2005-5249$ & $2005-2006-579$ \\
\hline $2005-2006-18189$ & $2005-2006-6966$ & \\
\hline
\end{tabular}

Additionally, the E-Learning Program grew from two schools with 60 students in 2004-2005 school year to five schools with over 200 students in the fall semester of 2005. Several additional school sites have indicated a desire to be part of the E-Learning Program as it expands during the spring of 2006.

Qualitative data has also been collected through faculty and student surveys, informal feedback via conferences and email, and formal feedback sessions with division and school district representatives, structured interviews by external evaluators, and written letters of thanks and support. All data collected has indicated a highly positive rate of approval for activities of The Center for Teaching and Learning. Annual evaluation of all components of the CTL allows decisions to be made to both sustain successful programs and to enhance programmatic offerings.

\section{Sustainability}

The administration of Delta State University has regularly demonstrated its commitment to sustaining all activities and initiatives of The Center for Teaching and Learning. While grant monies have allowed the development of the CTL's programmatic offerings, all can be sustained with funding from other sources. Faculty, staff, students, and the Office of Institutional Technology also have indicated their support of the initiatives of the Center for Teaching and Learning. The extensive offerings provided through initiatives of The Center for Teaching and Learning offer students and faculty at Delta State University and the greater Mississippi Delta Community the opportunity to be exposed to best practices and exemplary applications of technology. This exposure to technology will positively impact all those who participate in the initiatives of The Center for Teaching and Learning and further impact the lives of those whom they will teach.

\section{REFERENCES}

1. Baron, J., \& McKay, M. (April 2001). Designing and delivering an online course for k-12 educators. T.H.E. Journal, 28(9), 68-75.

2. Barron, A., \& Orwig, G. (1993). New technologies for education. Englewood, CO: Libraries Unlimited.

3. Blum, K. D. (1999). Gender differences in asynchronous learning in higher education: Learning styles, participation barriers and communication patterns. Journal of Axynchronous Learning Networks, 1(3). 
Retrieved May 13, 2006, from the World Wide Web: http://www.aln.org/alnweb/journal/Vol3_issue 1/blum.htm.

4. $\quad$ Bernard, R. Rojo de Rubaleava, B., \& St. Pierre, D. (2000). Collaborative online distance learning: Issues for future practice and research. Distance Education; An International Journal, 21(2), 290-299.

5. Cohen, V. (2000). Using the web to enhance field experiences for preservice teachers. Proceedings of Society for Information Technology and Teacher Education (SITE) 2000, San Diego, CA.

6. Creed, T. (1996). Extending the classroom walls electronically. Adapted from Campbell, W. and Smith, K. (Eds.). New Paradigms for College Teaching. Edina, MN: Interaction Book Co. [Online] Available: http://www.employees.csbsju.edu/tcreed/ecw.html.

7. Dibiase, David. (2000). Is Distance Education a Faustian Bargain? Journal of Geography in Higher Education, 24 (1) 130-136.

8. Ilinois Online Network (2000b). ION Resources: Synergy in the classroom. Retrieved March 15, 2004, from the World Wide Web: http://illinois.online.uillinois.edu/IONresources/instructionalDesign/index.html.

9. Kearsley, G. (2000). Online education; Learning and teaching in cyberspace. Belmont, CA: Wadsworth.

10. Market Retrieval Data Market Data Retrieval. (2002). Distance learning programs. The College Technology Review. Retrieved March January 31, 2005, from http://www.schooldata.com.

11. Palloff, R., \& Pratt, K. (1999). Building learning communities in cyberspace. San Francisco, CA: JosseyBass.

12. Schlosser, C.A., \& Anderson, M.L. (1994). Distance education: review of the literature. Washington, DC: Association for Educational Communications and Technology.

13. TaskStream Tools of Engagement. Retrieved May 18, 2006, from the World Wide Web: http://www.taskstream.com/pub/

14. US. Congress, Office of Technology Assessment. (1988). Power on! New tools for teaching and learning. OTA-SET-379. Washington, DC: US. Government Printing Office.

15. Vanderven, K. (1994,April). Viewpoint: The power and paradox of distance education. The On-line Chronicle of Distance Education and Communication [On-line journal] 7(2).Available Usenet Newsgroup alt.education.distance, May 3, 1994.

16. WebCT, A Blackboard Company. Retrieved May 14, 2006, from the World Wide Web: http://www.webct.com/vision.

17. Wolfe, L. (1994). The digital co-op: Trends in the virtual community. Paper presented at the Writers Retreat on Interactive Technology and Equipment. Vancouver, BC: The University of British Columbia Continuing Studies. 
NOTES 